\title{
Vitamin D3 Receptor
}

National Cancer Institute

\section{Source}

National Cancer Institute. Vitamin D3 Receptor. NCI Thesaurus. Code C17485.

Vitamin D3 receptor (427 aa, $\sim 48 \mathrm{kDa}$ ) is encoded by the human VDR gene. This protein is involved in vitamin D-mediated transcriptional regulation. 